\title{
Practice Aspects of Deposition of Nanostructured Composite NaCl-Fe Films by EB-PVD on a Rotating Substrate
}

\author{
V.O. Osokin11,*, Yu.A. Kurapov¹, Ya.A. Stel'makh1, P.O. Shpak ${ }^{2}$ \\ ${ }_{1}$ Paton Institute for Electric Welding, NASU, 11, Kazimir Malevich St., 03150 Kyiv, Ukraine \\ ${ }^{2}$ Institute for Carbon Nanomaterials, Ltd., office 110, build. 2, Khmelnitske St., 21036 Vinnitsa, Ukraine
}

(Received 26 July 2021; revised manuscript received 20 October 2021; published online 25 October 2021)

EB-PVD combines the feasibility of controlled intensive evaporation of nonorganic materials in vacuum with subsequent deposition of vapor on the substrate/product. This method is characterized by wide capabilities of various technological setups and precise control of technological process parameters. The paper considers peculiarities of the EB-PVD technological setup for obtaining nanostructured $\mathrm{NaCl}-\mathrm{Fe}$ materials for medical applications. A technological setup with a peripheral to the substrate rotation axis arrangement of vapor sources is employed. The use of a disk with a complex of inclined vapor channels on a vapor source ensures a uniform thickness distribution of thick $\mathrm{NaCl}$ films along a rotating substrate with an average thickness deviation of $\pm 5 \%$. The geometric ratio of the directions of vapors of source materials on a rotating substrate allows to obtain qualitative nanostructured $\mathrm{NaCl}-\mathrm{Fe}$ materials. The relative deviation of the concentration of the metal component does not exceed 8-10\%. The peripheral arrangement of vapor sources made it possible to reduce the distance between the sources of evaporating materials and the substrate deposition surface to $230 \mathrm{~mm}$. Thus, an increase in the film thickness up to $300-400 \mu \mathrm{m}$ is achieved. The structure of composite $\mathrm{NaCl}-\mathrm{Fe}$ films by EB-PVD on a rotating substrate is an alternation of $\mathrm{NaCl}$ and Fe enriched layers of different thickness that depends on the rotation speed of the substrate. An increase in the substrate rotation speed decreases the thickness of the deposited film layers. The results of X-ray phase analysis of the deposited composite $\mathrm{NaCl}-\mathrm{Fe}$ films reveal that $\mathrm{Fe}$ in the form of magnetite oxide $\mathrm{Fe}_{3} \mathrm{O}_{4}\left(\mathrm{FeO} \cdot \mathrm{Fe}_{2} \mathrm{O}_{3}\right)$ is included in the $\mathrm{NaCl}$ matrix. The size of the obtained $\mathrm{Fe}_{3} \mathrm{O}_{4}$ crystallites in the analyzed composite $\mathrm{NaCl}-\mathrm{Fe}$ films, obtained on a rotating substrate for an Fe content of 16.4-19.0\%, does not change with the thickness of the Fe layers and is $8 \pm 1 \mathrm{~nm}$. The presented results of experimental studies demonstrate the effective application of EB-PVD for obtaining various composite nanomaterials on rotating substrates.

Keywords: Nanomaterial, EB-PVD, Structure, Rotating substrate.

DOI: $10.21272 /$ jnep.13(5).05011

PACS numbers: 81.15.Jj, 81.05. - t

\section{INTRODUCTION}

The method of electron-beam physical evaporation of various materials in vacuum with subsequent vapor deposition on a substrate (EB-PVD) has capabilities to construct new materials in the form of thick films (up to $1 \mathrm{~mm}$ and higher), possesses high productivity and is capable of obtaining metal nanoparticles in different matrixes [1, 2, 5-7].

Microporous sodium chloride $(\mathrm{NaCl})$ formed by $\mathrm{EB}$ PVD is often used as a matrix for dispersed metal phase containment. The pressure of $\mathrm{NaCl}$ vapor allows its simultaneous deposition even with refractory materials. Such composites are promising for the production of various drugs due to their biocompatibility, minimal toxicity, and good solubility in water [1, 2].

The properties of Fe nanoparticles differ from those of macrocrystalline Fe. The melting point, electrical conductivity and energy of electron activation transitions - all depend on the size of Fe particles. The final size of the obtained Fe nanoparticles is also associated with their oxidation [3].

$\mathrm{NaCl}-\mathrm{Fe}$ materials with nanoparticles of $\mathrm{Fe}_{3} \mathrm{O}_{4}$ $\left(\mathrm{FeO} \cdot \mathrm{Fe}_{2} \mathrm{O}_{3}\right), \mathrm{Fe}_{2} \mathrm{O}_{3}$ oxides in a microporous matrix of $\mathrm{NaCl}$ show high efficiency in practical applications. For example, in medicine for targeted drug delivery and treatment of blood diseases.

The experimental data [1-3] confirm the possibility of obtaining NaCl-Fe materials by EB-PVD on stationary substrates. The geometrical arrangement of the stationary substrates with respect to the vapor sources leads to the formation of a gradient elemental composition of $\mathrm{NaCl}-\mathrm{Fe}$ films, increases the heterogeneity of their structure and limits the productivity of the deposition process.

The use of rotating substrates for the production of nanosized porous materials and metal nanoparticles is more promising, productive and technological. The rotation of the substrate changes the "shadowing" mechanism because it changes the angle of encounter of vapor and the deposition surface, which determines the formation of pores with micro- and nano-dimensions. The effect of "shadowing" is enhanced if the angle of vapor with the deposition surface is less than $90^{\circ}$, while the formation of the matrix phase affects the process of nucleation and growth of the second phase particles on the substrate surface $[4,5]$.

The goal of the present work was to study the technological aspects of production of nanostructured $\mathrm{NaCl}$ Fe materials (thick films) by EB-PVD on rotating substrates, their structure and some properties.

\section{EXPERIMENTAL}

Ingots of $\mathrm{NaCl}$ tablets and $\mathrm{Fe}$ were used for evaporation. $\mathrm{NaCl}$ tablets were prepared from $99.9 \%$ pure

\footnotetext{
*kist2002@ukr.net
} 
sodium chloride powder by pressing. Fe ingots for the experiments were obtained by double electron beam melting of $99.8 \%$ pure iron.

The technological setup for the deposition of composite $\mathrm{NaCl}-\mathrm{Fe}$ materials (thick films) on a rotating substrate is presented in Fig. 1.

The surface of the evaporated Fe ingot, located in the water-cooled copper crucible, was heated by an electron beam (EB) gun. In case of $\mathrm{NaCl}$, a graphite disk with a complex of vapor channels placed on the crucible with a $\mathrm{NaCl}$ tablet was heated by an EB-gun [2]. The deposition of $\mathrm{NaCl}$ vapor was oriented by the inclination of vapor channels to the middle of the radius $(110 \pm 10 \mathrm{~mm})$ of the rotating substrate $\left(V_{s}=1 \mathrm{rpm}^{-1}\right)$. The system of channels in the reactor at an angle of $30^{\circ}$ to the normal to the horizon prevents the direct contact of the electron beam with the surface of the $\mathrm{NaCl}$ tablet when the disk is heated, providing vapor to the substrate.

The resulting vapors are condensed on the rotating substrate with a diameter of $400 \mathrm{~mm}$ located above the crucibles. The vacuum level in the process chamber during evaporation was (1-2) $10^{-2} \mathrm{~Pa}$. The substrate temperature of $50-70^{\circ} \mathrm{C}$ was measured by thermocouples. The distance between the crucibles and the substrate was $230 \mathrm{~mm}$, the distance between the axes of the crucibles was $115 \mathrm{~mm}$. One composite $\mathrm{NaCl}-\mathrm{Fe}$ composite layer with a total thickness $H$, $\mu$ m consisting of $\mathrm{NaCl}$ and $\mathrm{Fe}$ enriched layers is deposited during one rotation period of the substrate over the mixed vapor. The speed of substrate rotation $V_{\mathrm{s}}$ was varied within 1 , $2,5,20$ and $25 \mathrm{rpm}^{-1}$.

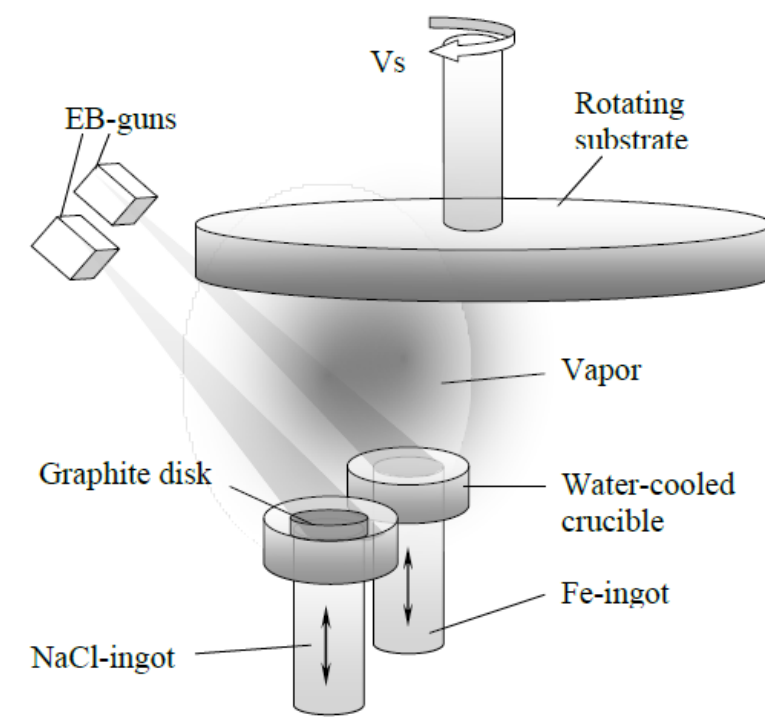

Fig. 1 - Setup for the deposition of composite $\mathrm{NaCl}-\mathrm{Fe}$ films on a rotating substrate

The concentration of $\mathrm{Fe}$ in the obtained films varied from 11 to 35 at. \%. The thickness of the of $\mathrm{NaCl}, h_{\mathrm{NaCl}}$, and $\mathrm{Fe}$ enriched, $h_{\mathrm{Fe}}$, layers in the composite varied from 0.56 to $1.43 \mu \mathrm{m}$ and from 0.11 to $0.64 \mu \mathrm{m}$, respectively, see Table 2 . The thickness of the composite layers and the concentration of $\mathrm{Fe}$ in the film were adjusted by the speed of substrate rotation and material evaporation intensity. The vapor deposition speed $\left(V_{k}\right)$ was $6-9 \mu \mathrm{m} \cdot \mathrm{min}^{-1}$, the total thickness of the obtained films was 80-400 $\mu \mathrm{m}$.

The microstructure of the deposited films was studied on cross-sections by SEM. Energy dispersive X-ray analysis was used to determine the elemental composition of $\mathrm{NaCl}-\mathrm{Fe}$ films. X-ray phase analysis of $\mathrm{NaCl}-\mathrm{Fe}$ films was carried out in filtered $\left(\mathrm{Co}-\mathrm{K}_{\alpha}\right)$ radiation with the Bragg-Brentano geometry in the angular range 10$85^{\circ}$. The average crystallite size was estimated by the Scherrer equation. Semi-quantitative phase analysis of the diffraction of the samples was completed using the Match program.

\section{RESULTS AND DISCUSSION}

For effective application of EB-PVD to a rotating substrate, geometry arrangement of the crucibles and the rotating substrate should be considered. To assess the influence of the geometrical parameters of the arrangement of vapor sources on the distribution of the thickness of the resulting film along the substrate radius $R_{s}$ (from the axis of rotation to the edge of the substrate), $\mathrm{NaCl}$ and $\mathrm{Fe}$ films were first deposited separately and their thickness distributions along the radius were measured.

$\mathrm{NaCl}$ films were obtained by evaporation through a graphite disk with a complex of vapor channels [2]. In this case, the direction of channels also determines the opening angle of vapor spreading. The electron beam power $W_{1}$ during the evaporation of $\mathrm{NaCl}$ was $1.8 \mathrm{~kW}$. A constant evaporation rate of the source material was ensured by its constant supply of $1.7 \mathrm{~g} \cdot \mathrm{min}^{-1}$. The evaporation time amounted to $15 \mathrm{~min}$. The distribution of the $\mathrm{NaCl}$ film thickness over the radius of the rotating substrate is shown in Fig. 2.

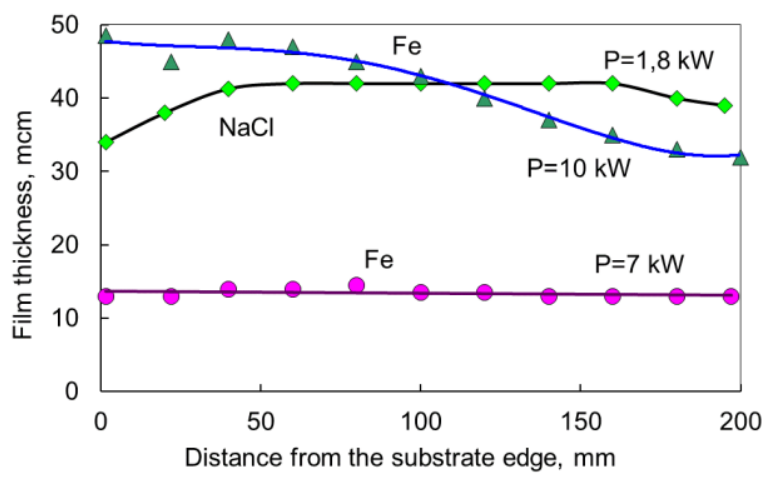

Fig. 2 - The thickness distribution for $\mathrm{Fe}$ and $\mathrm{NaCl}$ films along the substrate radius $\left(R_{s}\right)$

The thickness of the $\mathrm{NaCl}$ layer along the radius of the substrate ranges from 37 to $41 \mu \mathrm{m}$, i.e., its uniformity deviation is $\pm 5 \%$. This confirms the effectiveness of the inclined orientation of the graphite disk vapor channels towards the rotating substrate that ensures uniform deposition of the $\mathrm{NaCl}$ vapor.

Fe films were obtained by evaporation from another crucible located near $\mathrm{NaCl}$ crucible. Fe vapor was oriented directly to the edge of the rotating substrate by geometrical positioning of the crucible (Fig. 1). It is known that the area of effective use of the metal vapor is limited by a cone with an apex angle of $60^{\circ}$ [6]. This positioning of the crucible relative to the substrate also changed the angle of encounter of $\mathrm{Fe}$ vapor with the 
deposition surface in order to enhance the "shadowing" effect during the formation of micropores.

The Fe film was obtained in a $30 \mathrm{~min}$ technological process at an electron beam power $W_{1}=7.0 \mathrm{~kW}$. The Fe film thickness $14 \pm 1 \mu \mathrm{m}$ was practically uniform along the radius of the rotating substrate $\left(V_{s}=1 \mathrm{rpm}^{-1}\right)$, Fig. 2. Using the discussed deposition rates of $\mathrm{NaCl}$ and $\mathrm{Fe}$, composite films with a maximum $\mathrm{Fe}$ content of up to $14 \%$ were obtained.

To increase the Fe concentration in the composite $\mathrm{NaCl}-\mathrm{Fe}$ film and the overall productivity of the process, the electron beam power (and the corresponding $\mathrm{Fe}$ evaporation rate) was raised to $10 \mathrm{~kW}\left(V_{s}=2 \mathrm{rpm}^{-1}\right)$. In the high-intensity vapor region, the rate of Fe deposition increased from 0.47 to $1.5 \mu \mathrm{m} \cdot \mathrm{min}^{-1}$. It was experimentally determined that at an electron beam power $W=10 \mathrm{~kW}$ in a $30 \mathrm{~min}$ technological process, the thickness of the Fe film from the edge to the middle of the substrate radius increased by $30 \%$ to $45 \pm 1 \mu \mathrm{m}$ and decreased to $33 \mu \mathrm{m}$ closer to the axis of rotation.

Studies of the conditions of Fe vapor deposition on a rotating substrate revealed that the structure of a film is largely determined by the temperature of the substrate surface and depends both on the technological setup geometry and on the parameters of the technological process. A decrease in the distance between the evaporation surface of melted $\mathrm{Fe}$ with a temperature above $2000{ }^{\circ} \mathrm{C}$ and the rotating substrate from 400 to $230 \mathrm{~mm}$ leads to an increase in the substrate temperature from $40-45^{\circ} \mathrm{C}$ in case of a stationary one to 55 $70{ }^{\circ} \mathrm{C}$ in case of a rotating substrate. It is confirmed by theoretical and experimental studies by authors [7]

Table 1 - Speed of rotation along the substrate radius

\begin{tabular}{|c|c|c|c|}
\hline \multirow{2}{*}{$V_{s}, \mathrm{rpm}^{-1}$} & \multicolumn{3}{|c|}{ Substrate radius $R_{s}, \mathrm{~m}$} \\
\cline { 2 - 4 } & 0.20 & 0.14 & 0.02 \\
\cline { 2 - 4 } & \multicolumn{3}{|c|}{ Fe content, at. \% } \\
\hline 2 & 16.2 & 19.2 & 20.9 \\
\hline 5 & 27.9 & 31.8 & 31.7 \\
\hline 20 & 14.1 & 12.7 & 16.4 \\
\hline 25 & 21.1 & 22.7 & 22.4 \\
\hline
\end{tabular}

The relatively uniform thickness of Fe films along the radius of the substrate can be explained by different linear velocities of different substrate deposition regions (Table 1). Substrate points located at different radii from the axis of rotation have the same angular velocities, periods and frequencies, but different linear speeds. The farther a point is from the axis of rotation, the faster it moves above the Fe vapor. Wherein the substrate region distant from the rotation axis moves with a linear velocity of $0.05 \mathrm{~m} \cdot \mathrm{s}^{-1}$, the linear velocity of the substrate region near the rotation axis is $0.005 \mathrm{~m} \cdot \mathrm{s}^{-1}$, i.e., its periodic presence in $\mathrm{Fe}$ vapor is an order of magnitude less. This results in a uniform thickness of the film.

Thus, composite $\mathrm{NaCl}-\mathrm{Fe}$ films with a uniform $\mathrm{Fe}$ layer thickness and a maximum $\mathrm{Fe}$ content of up to $35 \%$ were deposited ( $W_{1}=10 \mathrm{~kW}$, Fig. 2$)$. The productivity of the synthesis of composite $\mathrm{NaCl}-\mathrm{Fe}$ films was tripled because of the stable metal phase content and an increase in the film thicknesses.
By adjusting the rate of evaporation and deposition of $\mathrm{Fe}$ vapor on a rotating substrate at $V_{s}=25 \mathrm{rpm}^{-1}$, composite $\mathrm{NaCl}-\mathrm{Fe}$ films of relatively uniform thickness were obtained (Fig. 3a). Thus, the technological parameters of the formation of composite $\mathrm{NaCl}-\mathrm{Fe}$ films of uniform thickness with different contents of the metal phase on a rotating substrate were determined.
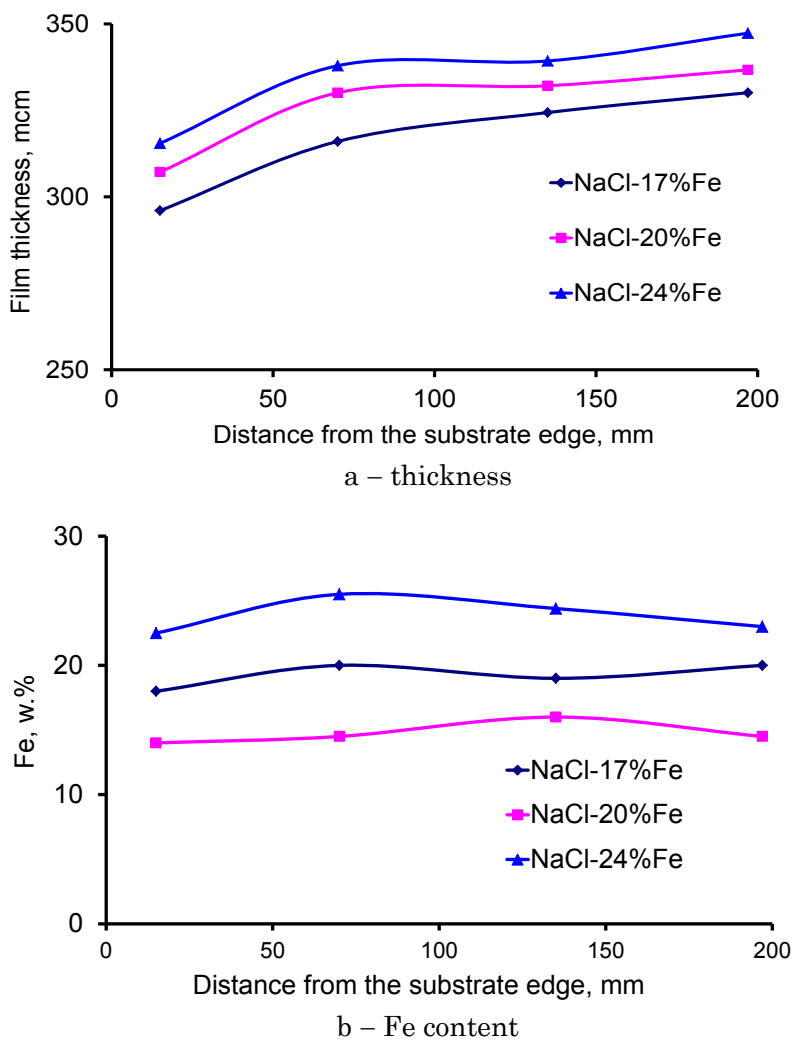

Fig. 3 - The total thickness (a) and Fe content (b) of composite $\mathrm{NaCl}-\mathrm{Fe}$ films along the radius $\left(R_{s}\right)$ of the rotating substrate $\left(V_{s}=25 \mathrm{rpm}^{-1}\right)$

The specified ratio of $\mathrm{NaCl}$ and $\mathrm{Fe}$ vapor orientation towards the rotating substrate made it possible to obtain high-quality $\mathrm{NaCl}-\mathrm{Fe}$ materials with a stable $\mathrm{Fe}$ content within $\pm 5 \%$ along the radius of the substrate (see Fig. 3b).

The dependences of the $\mathrm{O} / \mathrm{Fe}$ ratio in $\mathrm{NaCl}-\mathrm{Fe}$ composites along the radius of the rotating substrate $\left(V_{s}=2,20,25 \mathrm{rpm}^{-1}\right)$, depending on the Fe content, as one of the characteristics of nanostructured $\mathrm{NaCl}-\mathrm{Fe}$ films, is shown in Fig. 4. It is revealed that the $\mathrm{O} / \mathrm{Fe}$ atomic content ratio depends on the amount of $\mathrm{Fe}$ and decreases with an increase in its content in the film.

High activity of composite $\mathrm{NaCl}-\mathrm{Fe}$ films to oxygen can be explained by the presence of small size Fe nanoparticles in Fe enriched layers with high surface and chemical activity [8].

It was revealed that the size of the metal phase crystallites slightly increases with $\mathrm{Fe}$ content in the film (Fig. 5). The average size of $\mathrm{Fe}_{3} \mathrm{O}_{4}$ crystallites obtained on a rotating substrate is $60 \%$ higher than on a stationary substrate. X-ray phase analysis of composite $\mathrm{NaCl}-\mathrm{Fe}$ films revealed that sizes of $\mathrm{Fe}_{3} \mathrm{O}_{4}$ crystallites obtained on a rotating substrate are $7-9 \mathrm{~nm}$, while on a 


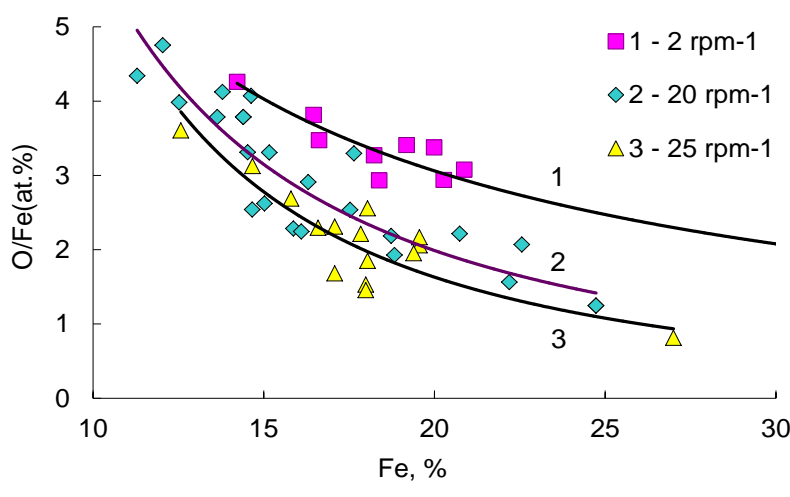

Fig. 4 - The $\mathrm{O} / \mathrm{Fe}$ ratio (at. \%) of composite $\mathrm{NaCl}-\mathrm{Fe}$ films on the $\mathrm{Fe}$ content, at. \%

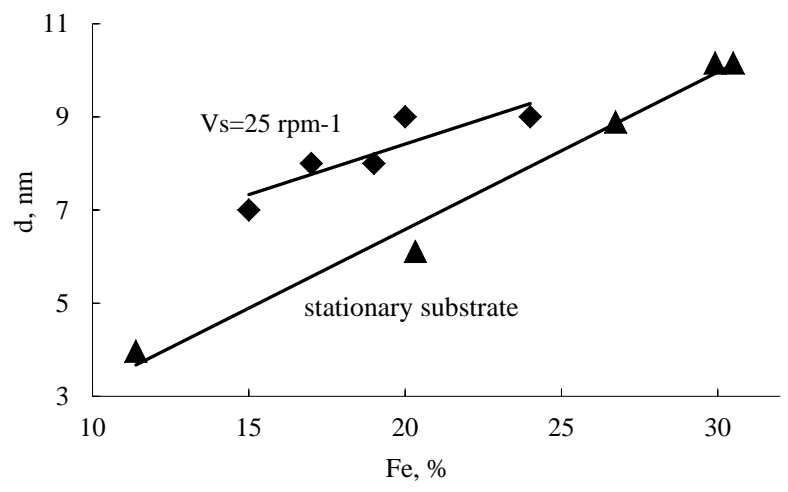

Fig. 5 - The average size of $\mathrm{Fe}_{3} \mathrm{O}_{4}$ crystallites in composite $\mathrm{NaCl}-\mathrm{Fe}$ films on the Fe content, at. \%

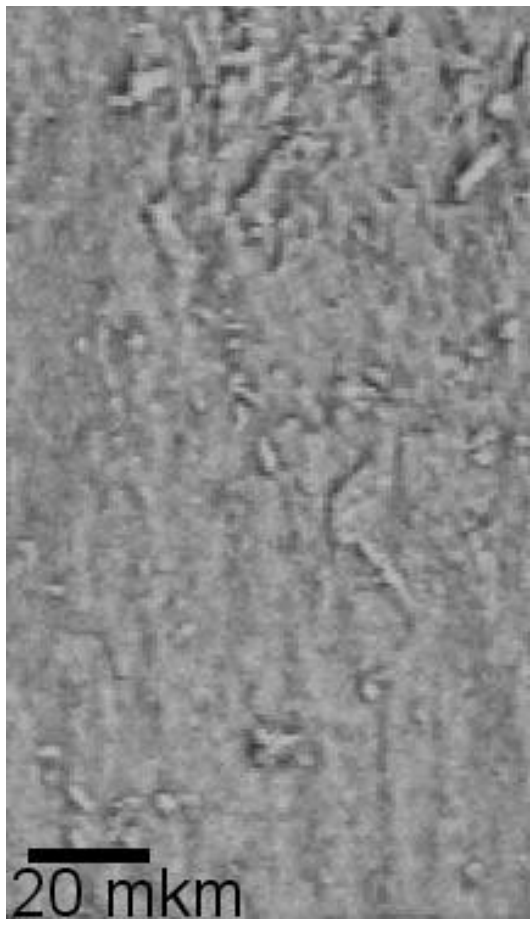

a - stationary substrate stationary substrate they are $4-10 \mathrm{~nm}$. The average increase in the crystallite size is due to an increase in temperature on the deposition surface of the rotating substrate, measured at $50-70{ }^{\circ} \mathrm{C}$ in comparison with $40-45^{\circ} \mathrm{C}$ of the stationary substrate. The study of the technological aspects of evaporation and deposition of $\mathrm{Fe}$ and $\mathrm{NaCl}$ vapors formed from separate sources made it possible to draw the following conclusions:

- composite $\mathrm{NaCl}-\mathrm{Fe}$ films with uniform thickness can be deposited by EB-PVD on rotating substrates. It is possible to control the elemental composition (components ratio) along the radius of the substrate within $\pm 5 \%$;

- arranged geometry of a rotating substrate relative to vapor sources allows to obtain homogeneous composite materials (thick films over 300-400 $\mu \mathrm{m}$ ) and triple productivity of their production by increasing the evaporation/deposition rate of raw materials and the deposition area of vapors.

It was revealed that the structure and properties of the deposited films are determined by two main factors: the thickness of the layers and the content of the metal phase. The microstructure of composite NaCl-Fe films obtained on stationary (a) and rotating (b) substrates at a deposition temperature of $50-70{ }^{\circ} \mathrm{C}$ are shown in Fig. 6. The deposition temperature corresponds to the first structural zone $T_{1} \leq 0.3 T_{\text {melt }} \mathrm{NaCl}$ and $\mathrm{Fe}$ [2].

The structure of composite $\mathrm{NaCl}-\mathrm{Fe}$ films deposited on a stationary substrate is a microporous matrix, consisting of randomly oriented crystallites (Fig. 6a).

The structure of composite NaCl-Fe films obtained on a rotating substrate (Fig. $6 \mathrm{~b}$ ) represents $\mathrm{NaCl}$ and Fe enriched alternating layers with thickness $(H, \mu \mathrm{m})$

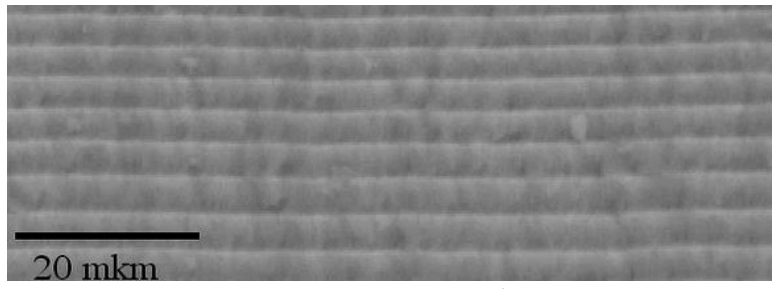

$V_{s}=2 \mathrm{rpm}^{-1}$

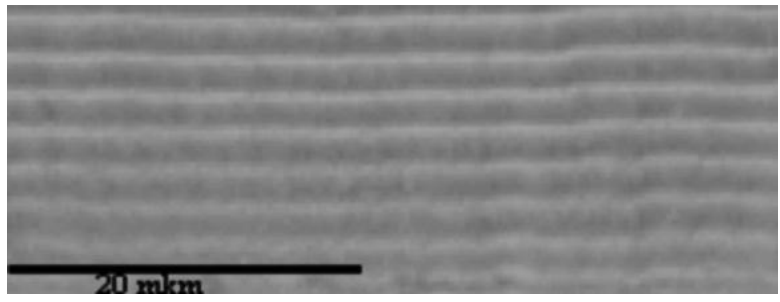

$V_{s}=5 \mathrm{rpm}^{-1}$

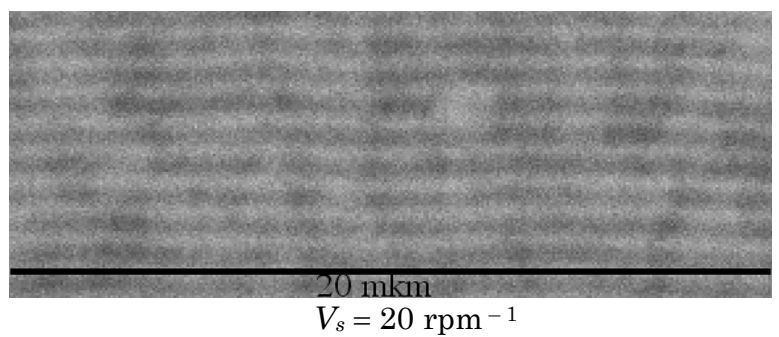

$\mathrm{b}$ - rotating substrate

Fig. 6 - Microstructure of cross-sections of composite NaCl-Fe films obtained on stationary (a) and rotating (b) substrates 
depending on the substrate rotation speed. A qualitative analysis of the microstructure indicates that an increase in the substrate rotation speed leads to a decrease in the thickness of the constituting layers of composite NaCl-Fe films.

Parameters of the layers of composite $\mathrm{NaCl}-\mathrm{Fe}$ films deposited at different substrate rotation speeds are shown in Table 2. At the substrate rotation speed $V_{s}=2 \mathrm{rpm}^{-1}$ the thickness of $\mathrm{NaCl}$ enriched layers is $3.25 \mu \mathrm{m}$, while the thickness of $\mathrm{Fe}$ enriched layers is $0.64 \mu \mathrm{m}$. The maximum average size of $\mathrm{NaCl}$ crystallites in the layers is about $45 \mathrm{~nm}$. The maximum size of $\mathrm{NaCl}$ crystallites deposited on a stationary substrate at $50{ }^{\circ} \mathrm{C}$ is $57 \mathrm{~nm}[2]$.

An increase in the rotation speed of the substrate to $25 \mathrm{rpm}^{-1}$ expectedly reduces the thickness of composite layers: $\mathrm{NaCl}$ enriched layers to $0.46 \mu \mathrm{m}$, while Fe enriched layers to $0.09 \mu \mathrm{m}(90 \mathrm{~nm})$. The ratio of the thickness of $\mathrm{NaCl}$ and $\mathrm{Fe}$ enriched layers of the studied composite multilayer $\mathrm{NaCl}-\mathrm{Fe}$ films remains constant at 0.2 .

Such a reduction in the thickness of $\mathrm{NaCl}$ and $\mathrm{Fe}$ enriched layers of the composite $\mathrm{NaCl}-\mathrm{Fe}$ film fully corresponds to the full period of substrate rotation in vapor (Table 2).

Table 2 - Characteristics of composite NaCl-Fe films

\begin{tabular}{|c|c|c|c|c|c|c|}
\hline $\begin{array}{c}V_{s}, \\
\mathrm{rpm}^{-1}\end{array}$ & $\begin{array}{c}t_{\exp }, \\
\min \end{array}$ & $\begin{array}{c}\text { Number of } \\
\text { layers, } N\end{array}$ & $\begin{array}{c}H, \\
\mu \mathrm{m}\end{array}$ & $\begin{array}{c}h_{\mathrm{NaCl}}, \\
\mu \mathrm{m}\end{array}$ & $\begin{array}{c}h_{\mathrm{Fe}}, \\
\mu \mathrm{m}\end{array}$ & $\begin{array}{c}h_{\mathrm{Fe}} / \\
h_{\mathrm{NaCl}}\end{array}$ \\
\hline 2 & 11 & 24 & 3.89 & 3.25 & 0.64 & 0.2 \\
\hline 5 & 2 & 10 & 1.77 & 1.43 & 0.34 & 0.2 \\
\hline 20 & 13 & 260 & 0.68 & 0.56 & 0.12 & 0.2 \\
\hline 20 & 20 & 400 & 0.63 & 0.52 & 0.11 & 0.2 \\
\hline 25 & 20 & 500 & 0.55 & 0.46 & 0.09 & 0.2 \\
\hline
\end{tabular}

Table 3 - Phase composition and average size of crystallite (d) of composite $\mathrm{NaCl}-\mathrm{Fe}$ films

\begin{tabular}{|c|c|c|c|c|c|}
\hline \multirow[b]{2}{*}{$\begin{array}{l}0^{0} \\
+\infty \\
0 \\
0 \\
0\end{array}$} & \multirow{2}{*}{ 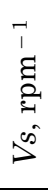 } & \multicolumn{2}{|c|}{$\begin{array}{c}\text { Thickness of } \\
\text { layers, } \mu \mathrm{m}\end{array}$} & \multicolumn{2}{|c|}{ Phase characteristics } \\
\hline & & $h_{\mathrm{NaCl}}$ & $h_{\mathrm{Fe}}$ & $\begin{array}{c}\text { Phase } \\
\text { composition }\end{array}$ & $\begin{array}{c}\text { Average size } \\
\text { of crystallites } \\
(d), \mathrm{nm}\end{array}$ \\
\hline 16.4 & 25 & 0.46 & 0.09 & $\mathrm{NaCl} / \mathrm{Fe}_{3} \mathrm{O}_{4}$ & $27 / 7$ \\
\hline 16.5 & 2 & 3.25 & 0.64 & $\mathrm{NaCl} / \mathrm{Fe}_{3} \mathrm{O}_{4}$ & $45 / 8$ \\
\hline 17.5 & 20 & 0.52 & 0.11 & $\mathrm{NaCl} / \mathrm{Fe}_{3} \mathrm{O}_{4}$ & $29 / 8$ \\
\hline 17.6 & 20 & 0.56 & 0.12 & $\mathrm{NaCl} / \mathrm{Fe}_{3} \mathrm{O}_{4}$ & $34 / 8$ \\
\hline 19.0 & 5 & 1.43 & 0.34 & $\mathrm{NaCl} / \mathrm{Fe}_{3} \mathrm{O}_{4}$ & $29 / 9$ \\
\hline
\end{tabular}

\section{REFERENCES}

1. I.S. Kovinsky, L.A. Krushinskaya, B.A. Movchan, $A d v$. Electrometallurgy 9, No 1, 41 (2011).

2. Y.A. Kurapov, B.A.Movchan, S.E. Litvin, G.G. Didikin, S.M. Romanenko, Adv. Electrometallurgy 9, No 2, 82 (2011).

3. Y.A. Kurapov, G.G. Didikin, S.M. Romanenko, S.E. Litvin, Adv. Electrometallurgy No 3, 26 (2009).

4. B.A. Movchan, K.Y. Yakovchuk, Adv. Electrometallurgy No 2 (2001).
The phase composition, the thickness of $\mathrm{NaCl}$ and $\mathrm{Fe}$ enriched layers and the corresponding crystallite sizes of composite $\mathrm{NaCl}-\mathrm{Fe}$ films obtained on a substrate with different rotation speeds are shown in Table 3.

$\mathrm{X}$-ray phase analysis of composite $\mathrm{NaCl}-\mathrm{Fe}$ films revealed that $\mathrm{Fe}$ is contained in the oxide form $\mathrm{Fe}_{3} \mathrm{O}_{4}$ in the $\mathrm{NaCl}$ matrix. The size of $\mathrm{Fe}_{3} \mathrm{O}_{4}$ crystallites in composite $\mathrm{NaCl}-16.4-19 \% \mathrm{Fe}$ films deposited on a rotating substrate does not correlate with the thickness of $\mathrm{Fe}$ enriched layers and is around $8 \pm 1 \mathrm{~nm}$.

The study of the elemental composition of crosssection samples of $\mathrm{NaCl}-\mathrm{Fe}$ films revealed the presence of oxygen, which presumably interacts with Fe during depressurization of the vacuum chamber after the completion of film deposition.

The ratio of the atomic content of oxygen to Fe depends on the amount of $\mathrm{Fe}$ and decreases with an increase in $\mathrm{Fe}$ and an increase in the rotation speed of the substrate (Fig. 5), which is the result of intensive oxidation of highly active Fe enriched layers.

Oxidation of $\mathrm{Fe}$ to $\mathrm{Fe}_{3} \mathrm{O}_{4}$ occurs during depressurization of the vacuum chamber and during the process of film separation from the substrate in air. Its integrity is violated, so the oxidation of Fe enriched layers is accelerated. When Fe interacts with oxygen, an exothermic reaction occurs with intense heat release. In some compositions, the measured temperature rise of the films separated from the substrate reaches $100{ }^{\circ} \mathrm{C}$ and above.

The presented results of experimental studies demonstrate the possibility of effective application of the physical processes of evaporation and deposition of various substances on a rotating substrate in vacuum to obtain nanoscale materials.

\section{CONCLUSIONS}

A new efficient technological method of deposition of thick (up to $400 \mu \mathrm{m}$ ) nanocomposite NaCl-Fe films by EB-PVD on a rotating substrate is proposed. Fe content is stable within $\pm 5 \%$ along the radius of the substrate and can be adjusted technologically.

Consistent patterns of change in the structural characteristics (including the thickness of $\mathrm{NaCl}$ and $\mathrm{Fe}$ enriched layers, as well as the metal phase content with the corresponding size of layer constituting crystallites) of nanocomposite $\mathrm{NaCl}-\mathrm{Fe}$ films relating to the arranged geometry of the technological setup and the rotation speed of the substrate are experimentally determined.

5. B.A. Movchan, Surf. Eng. 22, No 1, 35 (2006).

6. S.S. Blecherman, N.E. Ulion, Pat. US 3.628.994. USA. publ. 21.12.71.

7. G.F. Badilenko, V.F. Demchenko, O.B. Chuykov, Problemy spetsial'noy elektrometallurgii No 4 (1991) [In Russian].

8. K. Klabunde, G. Sergeev, Nanochemistry (Elsevier: 2013). 


\title{
Практичні аспекти отримання наноструктурних композитних $\mathrm{NaCl}-\mathrm{Fe}$ плівок способом EB-PVD на підкладках, що обертаються
}

\author{
В.О. Осокін ${ }^{1}$ Ю.А. Курапов ${ }^{1}$, Я.А. Стельмах ${ }^{1}$, П.О. Шпак²
}

${ }^{1}$ Інститут електрозварювання ім. С.О. Патона НАНУ, вул. Казилира Малевича, 11, 03150 Київ, Україна

2 Інститут вуглецевих нанолатеріалів, вул. Хлельнищьке шосе, 2, обріс 110, 21036 Віннищ,, Україна

Метод EB-PVD поєднуе можливості інтенсивного керованого випаровування різноманітних матеріалів у вакуумі з наступною конденсаціею отриманого парового потоку на охолоджуваній підкладці/виробі та характеризуеться широкими можливостями використання різноманітних технологічних схем, а також контролю та автоматизації параметрів проведення даного технологічного процесу. У роботі розглянуто деякі особливості використання технологічної схеми проведення EB-PVD процесу з периферичним відносно осі обертання підкладки розташуванням джерел випаровуваних матеріалів для отримання композиційних матеріалів $\mathrm{NaCl}-\mathrm{Fe}$, перспективних для застосування у медицині. Використання шайби з комплексом похилих парових каналів при випаровуванні $\mathrm{NaCl}$ забезпечило рівномірність розподілу товщини отримуваних плівок $\mathrm{NaCl}$ по радіусу підкладки з діаметром 400 мм, що обертається, із середнім відхиленням не більше $\pm 5 \%$. Розглянуте у роботі геометричне співвідношення направленостей парових потоків випаровуваних матеріалів на підкладщі, що обертається, дозволило отримати якісні композиційні матеріали $\mathrm{NaCl}-\mathrm{Fe} з$ відхиленням концентрації металевої складової, що не перевищуе 8-10 \%. Периферійне розташування джерел пари дозволило зменшити відстань між джерелами випаровуваних матеріалів та поверхнею осадження основи до 230 мм. Таким чином досягнуто збільшення товщини плівки до 300-400 мкм. Структура композиційних плівок $\mathrm{NaCl}-\mathrm{Fe}$, отриманих методом EB-PVD на обертовій підкладці, представляе собою чергування збагачених $\mathrm{NaCl}$ та $\mathrm{Fe}$ шарів різної товшини, яка залежить від швидкості обертання підкладки. Із збільшенням швидкості обертання підкладки відзначаеться зменшення загальної товщини одиничного композиту $\mathrm{NaCl}$ $\mathrm{Fe}$ Результати рентгенофазового аналізу отриманих композитів $\mathrm{NaCl}-\mathrm{Fe}$ виявили, що залізо перебуває у вигляді оксиду - магнетиту $\mathrm{Fe}_{3} \mathrm{O}_{4}\left(\mathrm{FeO} \cdot \mathrm{Fe}_{2} \mathrm{O}_{3}\right)$ у матриці $\mathrm{NaCl}$. При цьому розмір кристалітів $\mathrm{Fe}_{3} \mathrm{O}_{4}$ в плівках $\mathrm{NaCl}-16,4-19,0 \% \mathrm{Fe}$ не змінюеться з товщиною збагачених $\mathrm{Fe}$ шарів та становить $8 \pm 1$ нм. Наведені у роботі результати експериментальних досліджень підтверджують можливість ефективного використання фізичних процесів випаровування та конденсації на підкладках, що обертаються, різних матеріалів у вакуумі для отримання нанорозмірних матеріалів.

Ключові слова: Електронно-променеве осадження, Наноматеріал, Структура, Підкладка, що обертається. 